\title{
MEKANISME EUFEMISME DAN SENSORISASI: KEKERASAN SIMBOLIK DALAM TUTURAN DOSEN
}

\author{
Galieh Damayanti ${ }_{1,2}$, Trisna Andarwulan ${ }^{2}$, Aswadi $^{3}$ \\ ${ }_{1}^{1,2}$ Universitas Brawijaya, Jawa Timur \\ ${ }^{3}$ Universitas Muhammadiyah Sidenreng Rappang \\ Jalan Veteran Malang, Jawa Timur \\ Surel: galieh@ub.ac.id
}

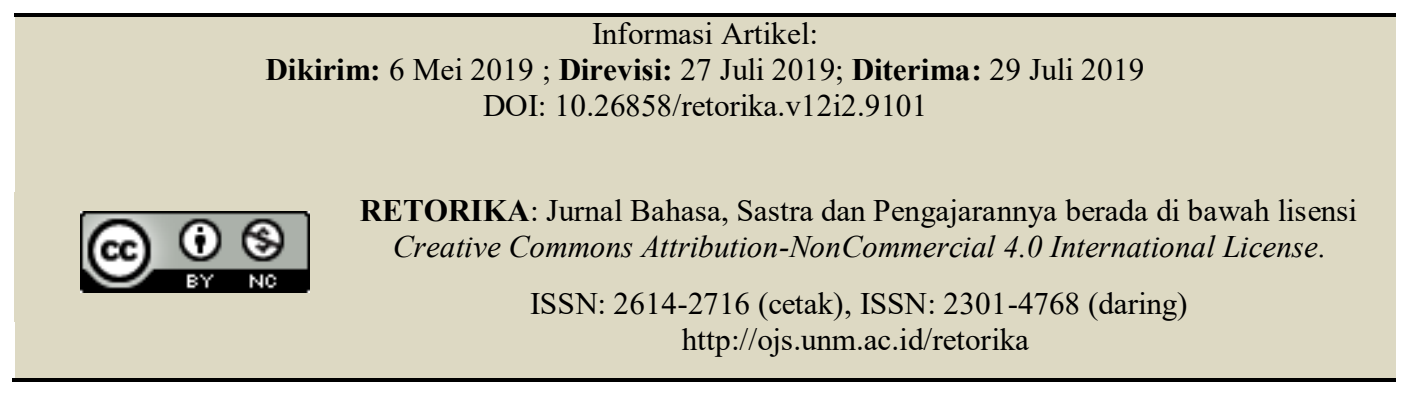

\begin{abstract}
Symbolic Violence Representation in the Mechanism of Euphemism and Sensorization of Lecturer Speech. This study aims to describe the representation of symbolic violence in the mechanism of euphemism and censorship of lecturers' speeches to students in the class. This study uses a qualitative approach with a type of case study research. Data in the form of sentences in lecturer speech to students. Data collection techniques used are observation, recording, and recording. Bourdieu's social class theory which was constructed in the mechanism of euphemism and censorship became the basis for studying this research data. Symbolic violence is represented in the mechanism of euphemism and the censorship mechanism. The results of the study show that symbolic violence through lecturer speech inspired by institutional authority shapes the behaviors, thoughts, and beliefs that can be accepted in certain social spaces. This is done on the basis of "to educate" students to behave and act better.
\end{abstract}

Keywords: symbolic violence; euphemism; censorship; lecturer speech

\begin{abstract}
Abstrak: Representasi Kekerasan Simbolik dalam Mekanisme Eufemisme dan Sensorisasi Tuturan Dosen. Penelitian ini bertujuan untuk mendeskripsikan representasi kekerasan simbolik dalam mekanisme eufemisme dan sensorisasi tuturan dosen terhadap mahasiswa di kelas. Penelitian ini menggunakan pendekatan kualitatif dengan jenis penelitian studi kasus. Data berupa kalimat dalam tuturan dosen kepada mahasiswa. Teknik pengumpulan data yang digunakan yaitu pengamatan, perekaman, dan pencatatan. Teori kelas sosial Bourdieu yang terkonstruksi dalam mekanisme eufemisme dan sensorisasi menjadi landasan dalam mengkaji data penelitian ini. Kekerasan simbolik terepresentasi dalam mekanisme eufemisme dan mekanisme. Hasil penelitian menunjukkan bahwa kekerasan simbolik melalui tuturan dosen yang diilhami oleh otoritas institusi membentuk perilaku, pemikiran, dan kepercayaan yang dapat diterima dalam ruang sosial tertentu. Hal ini dilakukan atas dasar "demi mendidik" mahasiswa untuk berperilaku dan bertindak lebih baik.
\end{abstract}

Kata kunci: kekerasan simbolik; eufemisme; sensorisasi; tuturan dosen 
Reformasi di Indonesia secara umum menuntut diterapkannya prinsip demokrasi, desentralisasi, keadilan, dan perlindungan hak asasi manusia dalam kehidupan berbangsa dan bernegara. Dalam kaitannya dengan dunia pendidikan, prinsip-prinsip tersebut akan memberikan dampak yang mendasar pada sistem pendidikan nasional sesuai amanat Pasal 31 ayat (1) Undang-Undang Dasar Negara Republik Indonesia tahun 1945 yang menyebutkan bahwa setiap warga negara berhak mendapat pendi-dikan, dan ayat (5) yang menegaskan bahwa pemerintah memajukan ilmu pengetahuan dan teknologi dengan menjunjung tinggi nilai-nilai agama dan persatuan bangsa untuk kemajuan peradaban serta kesejahteraan umat manusia.

Ruang pendidikan merupakan wadah transfer ilmu, proses pengembangan diri individu secara menyeluruh dalam lingkungan masyarakat sosial. Pendidikan merujuk pendapat Dewey (dalam Jalaluddin, 2001) sebagai fungsi sosial, bimbingan, sarana pertumbuhan yang mempersiapkan dan membukakan, serta membentuk disiplin hidup. Salah satu pelaku pendidikan adalah pendidik atau guru atau dosen. Fungsi pendidik, salah satunya, menjadikan peserta didik menjadi warga negara yang baik, disiplin terhadap segala peraturan perundang-undangan yang berlaku atas dasar Pancasila dan UU RI 1945 (Daradjat, 2002:95).

Bernstein (2000:32) memahami disiplin sebagai 'wacana regulatif' yang sebenarnya mendominasi 'wacana instruksional', upaya pendidik untuk mengembangkan keterampilan khusus peserta didik dan keahlian konten melalui penyampaian kurikulum. Fungsi pendidik, yakni menjadikan disiplin, dalam pandangan tersebut menunjukkan bahwa retorika pedagogis seputar teknik pengajaran dan tujuan pencapaian aka-demik sering berfungsi sebagai 'suara rahasia' yang tujuannya untuk 'menyamarkan fakta bahwa ada kontrol melalui disiplin.

Upaya pendisiplinan pendidik melalui bahasa tentunya tidak terlepas dari kuasa pendidik. Kuasa pendidik dapat dikategorikan dalam tindakan membungkam, menghukum, menekan, mengendalikan, mengarahkan, maupun membentuk perilaku. Dalam kaitannya dengan hal tersebut, Foucault (1995:138) memberi label disiplin sebagai 'kebijakan pemaksaan'. Dalam posisi ini memunculkan pola relasi simetris antara pendidik dengan peserta didik. Peserta didik sebagai penerima disiplin akan dengan terpaksa atau tidak, mengikuti arahan pendidik. Hal tersebut disebabkan oleh adanya relasi kekuasaan yang timpang dan hegemoni, pihak yang satu memandang diri lebih superior baik dari segi moral, etis, agama, jenis kelamin ataupun usia, sementara pihak yang lain sebaliknya. Kondisi ini sangat memungkinkan terjadinya kekerasan simbolik.

Praktik kekerasan simbolik dalam pendidikan merupakan hal yang sulit dilihat dan dipahami dampaknya secara langsung. Namun, tindak kekerasan ini dapat dipertimbangkan dari kekuasaan wacana yang membentuk dan membangun tindak kekerasan tersebut (Gold-stein, 2005). Menurut Bourdieu (1991:75) kekuatan simbolis dan kekerasan dalam institusi, melalui individu-individu yang diilhami oleh otoritas institusi membentuk perilaku, pemikiran, dan kepercayaan yang dapat diterima dalam ruang sosial tertentu. Hal ini karena institusi itu sendiri menempatkan individu-individu tertentu sebagai juru bicara untuk institusinya. Individu-individu tersebut, misalnya pendidik, melengkapi dirinya dengan tanda-tanda dan lambang yang bertujuan menjelaskan fakta bahwa mereka tidak bertindak atas nama mereka sendiri dan di bawah otoritas mereka sendiri. Melalui kekuatan simbolis, pendidik melakukan tindak kekerasan atas nama institusi yang mereka layani.

Kebijakan semacam itu memungkinkan adanya kekerasan institusional karena menyiratkan bahwa mereka yang menentang kebijakan semacam itu secara sadar memilih untuk dinyatakan menyimpang. Norma-norma perilaku terinternalisasi dalam praktik-praktik sosial dan dipandang sebagai apa adanya, sebagaimana adanya, dan seperti apa adanya. Selanjutnya, mereka berfungsi sebagai kekerasan institusional karena mengorbankan peserta didik, membentuk siapa mereka seharusnya.

Kontruksi kekerasan simbolik dalam pendidikan dapat dilakukan melalui eufemisme dan sensorisasi (Rusdiarti, 2003:38). Eufemisme adalah mekanisme kekerasan simbolik yang tidak tampak bekerja secara halus, tidak dike-nali, dan berlangsung di bawah alam bawah sadar. Bentuk-bentuk eufemisme dapat berupa kepercayaan, kewajiban, kesetiaan, sopan santun, pemberian, amal, pahala, belas kasihan. Eufemisme bekerja atas dasar keharusan dan kebaikan. Kepercayaan, kewajiban, dan kesediaan adalah wujud eufemisme yang diciptakan atas dasar keharusan. Mekanisme bekerja dengan menciptakan 
situasi kognitif bagi subjek dalam keadaan tanpa pilihan. Nilai-nilai kebaikan disusupkan untuk menegakkan pengaruh dan merebut atau memperkokoh kekuasaan. Sementara itu, sensorisasi yaitu mekanisme kekerasan simbolik yang menjadikannya tampak sebagai bentuk sebuah pelestarian semua bentuk nilai yang dianggap sebagai "kehormatan moral" yang biasanya dipertentangkan dengan "moral rendah".

Bahasa menjadi dalam melanggengkan kuasa pendidik secara halus. Dengan menggunakan alasan "kehormatan moral" dan "moral rendah", seorang pendidik sering melakukan tindak kekerasan dengan alasan menegakkan disiplin. Peserta didik secara tidak langsung dipaksa untuk menerima nilai-nilai yang dipersepsikan dengan baik tanpa mampu berpikir kritis. Alih-alih sebagai bentuk kepedulian pendidik terhadap peserta didik, segala tindak kekerasan verbal yang terjadi seolah menjadi keharusan yang 'berterima' sebagai suatu kebaikan. Dengan kata lain, kekerasan simbolik bekerja sangat efektif sebagai instrumen kontrol. Padahal, kekerasan simbolik memberikan dampak yang sangat besar bagi peserta didik, baik secara psikis maupun mental. Bahkan, dalam situasi tertentu, tindak kekerasan tersebut bisa berdampak pada perilaku anarkis peserta didik yang menentang pendidik.

Seseorang yang mengalami kekerasan sibolik memperoleh sikap yang tidak teratur, termasuk dalam kebebasan dan kendali. Dengan demikian, dalam kaitannya dengan kekerasan simbolik, konsep-konsep ini merujuk pada pandangan bahwa paksaan yang dibentuk hanya melalui persetujuan yang tidak dapat gagal diberikan oleh pihak yang mendominasi kepada pihak yang terdominasi, ketika pemahaman mereka tentang situasi dan hubungan hanya dapat menggunakan instrumen pengetahuan yang mereka miliki bersama dengan dominator, yang hanya sebagai bentuk, yang disatukan dari struktur hubungan dominasi, membuat hubungan ini tampak alami (Bourdieu, 2000:170).

Dalam ruang institusi pendidikan, praktik-praktik kekerasan simbolik dapat terjadi antara atasan dengan bawahan, antara guru dengan siswa atau dosen dengan mahasiswa. Pola pendidikan Indonesia yang terkesan menggurui, menanamkan doktrin-doktrin tunggal, memba-tasi kreativitas, bahkan hanya menguji hafalan semata makin menguatkan praktik kekerasan simbolik. Hal ini diperparah dengan sikap pendidik yang terlalu dominan, dengan meletakkan pe- serta didik hanya sebagai objek. Praktik-praktik ini, dalam lingkup pembelajaran antara dosen dengan mahasiswa, misalnya, dilakukan atas dasar alih-alih "demi mendidik", yang bertujuan untuk membentuk perilaku dan sikap yang lebih baik. Kondisi ini didukung pula adanya doktrin 'haram' atau 'kuwalat' hukumnya bila melawan dosen yang merupakan panutan, orang yang "digugu" dalam lingkungan pendidikan.

Kasus yang baru-baru ini ramai diperbincangkan, yakni adanya perilaku kekerasan seksual dosen kepada mahasiswa (tirto.id, 17 Mei 2019). Kasus ini merupakan bentuk kekerasan yang terjadi dalam ruang pendidikan. Alih-alih mendidik, memberikan bekal ilmu dan etika yang baik pada mahasiswa, mereka menggunakan kuasa status 'dosen' untuk memperdaya mahasiswa. Dosen memiliki kuasa yang dominan yang sulit dilawan mahasiswa. Walaupun mahasiswa merupakan pelajar dewasa, yang memiliki kemampuan berpikir logis dan kritis di atas level jenjang sekolah, mereka dibuat patuh terhadap kebijakan yang dibuat oleh perguruan tinggi mereka berada. Kasus tersebut sangat disayangkan mengingat dosen merupakan salah satu penentu kesuksesan mahasiswa.

Selain kasus di atas, penelitian tentang kekerasan dalam ruang pendidikan juga dilaku-kan oleh Ulfah (2013; 2014) dan Amirulloh (2018). Penelitian Ulfah (2013) berjudul "Kekerasan Simbolik dalam Wacana Pembelajaran". Penelitiannya bertujuan mendeskripsikan bentuk kekerasan simbolik dalam mekanisme eufemisme dan sensorisasi. Hasil penelitiannya menunjukkan bahwa terdapat beragam mekanisme eufemisme dan sensorisari yang direpresentasikan dalam wacana pembelajaran. Penelitian Ulfah (2014) berjudul "Eufemisme sebagai Mekanisme Kekerasan Simbolik dalam Pembelajaran di Sekolah". Penelitiannya memfokuskan pada wujud-wujud eufemisme dalam pembelajaran di sekolah, yang antara lain berupa perintah, pemberian bonus, kepercayaan, dan larangan. Penelitian Amrulloh (2018) berjudul "Kekerasan Simbolik dalam Mewujudkan Eko-sistem Pendidikan Kondusif di MAN Kota Batu. Hasil penelitiannya menunjukkan bahwa tidak ada niatan dari pihak sekolah untuk melakukan kekerasan atas dasar kekuasaan yang mereka miliki. Tindakan tegas yang dilakukan semata-mata sebagai proses pendisiplinan kepada peserta didik. Tindakan tersebut ditujukan supaya peserta didik memiliki 'moral kehormatan' yang berguna bagi mereka 
dan menciptakan eko-sistem pendidikan yang kondusif.

Bila ditilik, kasus yang diuraikan di atas sama-sama menjelaskan tentang tindak kekerasan dalam ruang pendidikan, namun berbeda jenisnya. Kasus pertama sudah mengarah pada bentuk kekerasan fisik, sementara kasus yang dilakukan oleh kedua peneliti tersebut mengarah pada bentuk kekerasan simbolik. Walaupun demikian, kasus tersebut menunjukkan bahwa tindak kekerasan dalam institusi pendidikan kerap terjadi. Berkaitan dengan hal tersebut, penelitian ini berfokus pada kekerasan simbolik. Hal ini karena kekerasan simbolik memiliki efek besar. Kekerasan simbolik yang dilakukan secara kontinu dapat dimungkinkan mengakibatkan adanya kekerasan fisik.

Berdasar uraian di atas, penelitian ini bertujuan untuk mendeskripsikan representasi kekerasan simbolik dalam mekanisme eufemis-me dan sensorisasi tuturan dosen di kelas. Penelitian ini berbeda dengan penelitian sebelumnya karena subjeknya berbeda. Pada penelitian ini, subjek kajiannya yaitu di perguruan tinggi.

\section{METODE}

Penelitian ini menggunakan pendekatan kualitatif dengan jenis penelitian studi kasus. Penelitian ini dilakukan di semester ganjil, yakni pada Agustus sampai dengan Desember 2018 yang berlokasi di Fakultas Ilmu Administrasi, Universitas Brawijaya. Data penelitian berupa kalimat yang diambil dari tuturan dosen kepada mahasiswa yang terjadi dalam kegiatan pembelajaran di kelas. Sumber data penelitian ini adalah teks lisan tuturan dosen terhadap mahasiswa dalam kegiatan pembelajaran di kelas. Di samping melakukan pengamatan, peneliti juga mencatat peristiwa dalam kegiatan pembelajaran, yaitu suasana atau keadaan dan aktivitas pembelajaran yang juga digunakan sebagai sumber data.

Teknik pengumpulan data yang digunakan yaitu pengamatan, perekaman, dan pencatatan. Dalam kegiatan pengumpulan data, peneliti menggunakan panduan yang berisi tentang (1) panduan pencatatan lapangan, (2) panduan pengumpulan data, dan (3) panduan perekaman teks lisan sumber data. Analisis data penelitian dilakukan melalui model Miles dan Huberman (2014), yaitu: (1) reduksi data, (2) penyajian data, dan (3) penyimpulan data.
Teori yang digunakan dalam mendeskripsikan data penelitian representasi kekerasan simbolik dalam mekanisme eufemisme dan sensorisasi tuturan dosen terhadap mahasiswa, yaitu teori kelas sosial Bourdieu. Beberapa konsep utama dalam pandangan Bourdieu untuk menjelaskan kekerasan simbolik, yaitu modal, kelas, habitus, kekerasan dan kekuasaan. Konsep ini terkonstruksi dalam mekanisme eufemisme dan sensorisasi (Rusdiarti, 2003; Martono, 2012) yang sebagian ahli menyebutnya dengan istilah misrecognition (legitimasi), condescension (merendahkan) dan complicity/ consent (keterlibatan/ persetujuan) (Thapar, dkk., 2016).

\section{HASIL DAN PEMBAHASAN}

\section{Hasil}

Hasil penelitian menunjukkan bahwa representasi kekerasan simbolik terjadi dalam mekanisme eufemisme dan sensorisasi tuturan dosen di kelas. Bentuk eufemisme dalam tuturan dosen berupa (1) keharusan/ kewajiban, (2) efisiensi, (3) pemberian bonus, (4) kepercayaan, (5) pencitraan, (6) kegunaan, (7) keselarasan, (8) kemurahatian/ kebaikan, dan (9) penegasan; sementara bentuk sensorisasi tuturan dosen berupa (1) kedermawanan, (2) kesantunan, dan (3) pemarginalan. Hasil penelitian representasi kekerasan simbolik dalam mekanisme eufemisme dan sensorisasi tuturan dosen di kelas dipaparkan berikut ini.

Mekanisme eufemisme yang ditemukan dalam penelitian ini terdiri atas sembilan bentuk, yaitu (1) keharusan/ kewajiban, (2) efisiensi, (3) pemberian bonus, (4) kepercayaan, (5) pencitraan, (6) kegunaan, (7) keselarasan, (8) kemurahatian/ kebaikan, dan (9) penegasan. Masingmasing bentuk diuraikan dalam paparan berikut.

Pertama, keharusan/kewajiban. Keharusan/kewajiban adalah bentuk eufemis-me yang dilakukan dosen untuk menegaskan kepada mahasiswa agar melakukan atau menjalankan sesuatu yang diperintahkan. Eufemisme jenis ini dapat dilihat pada beberapa data berikut.

(1) D: (menatap mahasiswa yang wajahnya terlihat kusam dan lelah) "Cuci muka sana biar fokus!"

M: .... (tidak menjawab dan bergegas meninggalkan kelas).

(2) D: "Kamu yang di belakang, pindah ke 
depan agar saya bisa lihat dengan jelas!" (melihat mahasiswa karena banyak yang mengisi bangku di baris belakang, sementara baris depan kosong).

M:"Iya Pak." (berdiri sambil membawa tas dan berjalan ke bangku depan)

(3) D: "Kamu yang harusnya menghubungi saya, masa begitu saja nda mengerti!"

M: ...." (diam dan menunduk)

Data (1) terjadi saat dosen bertanya jawab dengan mahasiswa tentang topik yang dipelajari. Mahasiswa tampak tidak menyimak penjelasan yang disampaikan dosen sehingga tidak menjawab pertanyaan dosen. Dosen yang melihat mahasiswa tersebut kemudian memerintahkannya dengan menggunakan kalimat perintah berintonasi nada tinggi. Tuturan perintah dosen tersebut telah merepresentasikan kekerasan simbolik. Dengan menggunakan kuasanya, mahasiswa harus/wajib mengikuti perintah dosen. Penggunaan diksi "cuci muka" dan "fokus." Menunjukkan adanya mekanisme eufemisme. Ketidaksiapannya menjawab bisa diindikasikan mahasiswa tersebut sedang tidak fokus, lelah, atau mengantuk sehingga dengan mencuci muka pikirannya menjadi fokus kembali. Di sisi lain, cuci muka tersebut bisa diindikasikan dosen kesal melihat wajah mahasiswa tersebut.

Data (2) terjadi ketika proses pembelajaran akan segera dimulai. Dosen memerhatikan posisi duduk mahasiswa. Mahasiswa tidak ada yang menempati baris pertama dan kedua sehingga dosen menyuruh mereka untuk mengisi baris tersebut. Tiga mahasiswa akhirnya berpindah posisi ke depan. Pada konteks ini, mahasiswa tidak dihadapkan pada pilihan lain selain mengikuti arahan dosen. alih-alih ketercapaian pembelajaran, posisi duduk menjadi hal yang diutamakan. Kondisi tersebut menunjukkan adanya kekerasan simbolik pada mahasiswa. Penggunaan eufemisme "pindah agar jelas" menjadi alasan pembenaran hal tersebut.

Data (3) terjadi saat akan memulai proses pembelajaran. Dosen menyalahkan mahasiswa karena tidak ada yang menghubunginya untuk mengingatkan adanya perkuliahan di kelas tersebut. Akibatnya dosen masuk kelas tersebut di saat jam perkuliahan akan segera usai. Pada konteks ini, mahasiswa seolah-olah menjadi pihak yang bersalah. Padahal, mahasiswa seha-rusnya yang dirugikan karena tidak mendapat perkuliah- an dari dosen tersebut. Kondisi ini menunjukkan adanya kekerasan simbolik pada mahasiswa. Penggunaan eufemisme "...masa begitu saja nda mengerti" mengindikasikan bahwa mahasiswa adalah orang yang bodoh, tidak proaktif, tidak kritis.

Dari tiga contoh kutipan di atas menunjukkan bahwa eufemisme dengan keharusan/ kewajiban mengindikasikan adanya hal-hal yang wajib dipahami dan dikuasai mahasiswa, namun yang terjadi, mahasiswa tidak melakukannya dengan benar.

Kedua, efisiensi. Efisiensi pada wujud eufemisme adalah ketepatan cara dalam mengerjakan sesuatu dengan tidak membuang-buang waktu, tenaga, dan biaya. Eufemisme dalam bentuk efisiensi dapat dilihat pada data berikut.

(4) D: "Siapkan kertas. Tulis nama. Kerjajakan dalam waktu 30 menit!"

M: "Iya Pak" (mahasiswa menjawab kompak).

(5) D: "Sambil menunggu temanmu menjawab, coba kamu ulangi penjelasan temanmu tadi!"

M: .... (diam dan berpikir).

(6) D: "Kamu yang di belakang, daripada melamun, coba jelaskan topik ini di depan!"

M: .... (berjalan ke depan sesuai dengan yang ditunjuk oleh dosen).

Data (4) dituturkan oleh dosen kepada mahasiswa saat perkuliahan berlangsung. Dosen dengan tiba-tiba meminta mahasiswa untuk menyiapkan kertas dan memberi soal. Tuturan dosen dimaksudkan agar mahasiswa dapat mengerjakan soal secara tepat waktu. Namun demikian, dosen perlu juga mempertimbangkan jumlah dan bobot soal dengan rentang waktu yang diberikan. Bila jumlah soal cukup banyak dan bobot soal cukup kompleks, rentang waktu yang diberikan seharusnya lebih banyak dari yang diujarkan. Kondisi ini menunjukkan adanya kekerasan simbolik yang dilakukan dosen terhadap mahasiswa. Dominasi dosen menyebabkan mahasiswa merasa tertekan/ terintimasi dengan waktu yang diberikan dosen. Padahal, ukuran ketercapaian pembelajaran tidak didasarkan pada waktu tetapi pada penyelesaian dan ketepatan menjawab soal mahasiswa.

Data (5) dituturkan oleh dosen kepada salah satu mahasiswa saat proses pembelajaran berlangsung. Kegiatan yang berlangsung saat itu 
adalah kegiatan presentasi yang dilakukan mahasiswa. Beberapa mahasiswa dalam satu kelompok sedang presentasi dan mahasiswa lain menyimak. Saat kegiatan berlangsung, dosen memperhatikan salah satu mahasiswa yang terlihat tidak menyimak penjelasan temannya. Mahasiswa tersebut ditunjuk oleh dosen untuk mengulangi penjelasan yang disampaikan kelompok presentasi. Dengan otoritas dosen tersebut, mahasiswa mau tidak mau harus memperhatikan penjelasan yang disampaikan di muka kelas, baik oleh dosen maupun mahasiswa lain yang sedang presentasi. Tidak jauh berbeda dengan data (5), data (6) juga menunjukkan adanya otoritas dosen kepada mahasiswa. Tuturan tersebut terjadi ketika dosen sedang menjelaskan suatu topik terhadap mahasiswa dan secara tiba-tiba menunjuk salah satu mahasiswa untuk mengulangi penjelasan yang disampaikannya. Penggunaan eufemisme "dari pada melamun lebih baik baik menjelaskan materi" mengindikasikan adanya kekerasan simbolik yang dilakukan dosen terhadap mahasiswa. di satu sisi, ini menjadi hal positif ketika mahasiswa memahami topik yang diajarkan tersebut, namun di sisi lain ini menjadi hal negatif ketika mahasiswa masih belum memahami topik yang diajarkan. Hal ini menjelaskan bahwa tidak semua mahasiswa "siap" dengan materi yang diajarkan dosen.

Ketiga, pemberian bonus. Pemberian bonus adalah wujud eufemisme yang dilakukan dosen untuk memberikan motivasi kepada mahasiswa untuk lebih giat belajar. Eufemisme jenis ini dapat dilihat pada data berikut.

(7) D: "Yang bisa menjawab, saya beri poin 10 !"

M: .... (Diam menyimak dosen dan beberapa mahasiswa ada yang membuka buku catatan).

(8) D: "Yang bisa menjawab, boleh mninggalkan kelas!"

M: .... (memperhatikan dengan serius dengan ekspresi waswas).

(9) D: "Yang bisa menjawab semua soal dengan benar, saya beri hadiah!"

M: "Asyek." (gumam beberapa mahasiswa).

Walaupun ketiga data di atas berfungsi untuk memotivasi mahasiswa, tujuan dari ketiga data di atas sebenarnya adalah mengintimidasi mahasiswa. Data (7) diujarkan dosen karena mahasiswa tidak antusias dalam mengikuti pem- belajaran. Dosen memancing mahasiswa dengan pemberian poin agar mereka terlibat aktif dalam kegiatan pembelajaran, walau pada kenyatannya banyak pula yang tidak dapat menjawab dengan tepat dan lengkap.

Data (8) diujarkan dosen saat pembelajaran akan usai. Tuturan tersebut berfungsi untuk memancing ingatan mahasiswa akan materi yang baru saja mereka terima.

Data (9) diujarkan dosen saat akan memberikan soal UTS kepada mahasiswa. Tuturan tersebut berfungsi memberikan motivasi kepada mahasiswa agar mengerjakan soal dengan sungguh-sungguh, walaupun Kenyataanya tidak ada yang menjawab dengan benar semua soal yang diberikan oleh dosen. Dari ketiga data tersebut menunjukkan bahwa pem-berian bonus menjadi hal yang penting dalam pembelajaran. Pemberian bonus merupakan salah satu bentuk penghargaan dosen terhadap mahasiswa terlepas hal tersebut memiliki efek positif atau justru negatif.

Keempat, kepercayaan. Kepercayaan adalah bentuk eufemisme yang dilakukan oleh dosen untuk memberikan keyakinan kepada mahasiswa tentang sesuatu yang diyakini kebenarannya. Bentuk eufemisme ini dapat dilihat pada data berikut.

(10) D: "Karena sudah belajar, pasti mudahlah soal ini buat kalian."

M: "Soalnya jangan sulit-sulit Pak."

(komentar salah satu mahasiswa)

(11)D: "15 menit saja sudah cukup untuk mengerjakan soal ini, kelas ini kan rajin-rajin mahasiwanya."

M: .... (terdiam dan memperhatikan soal yang diberikan dosen)

Data (10) dituturkan oleh dosen kepada mahasiswa saat memberikan soal ujian. Mahasiswa seolah-olah ditegaskan oleh dosen bahwa soal yang diberikan itu mudah. Dalam konteks ini, mahasiswa bisa jadi merasa terbebani dengan pernyataan dosen tersebut. Bila mahasiswa tidak bisa menjawab dengan benar, mereka sudah merusak kepercayaan yang diberikan oleh dosennya.

Data (11) dituturkan oleh dosen kepada mahasiswa saat memulai perkuliahan. Dosen memberikan kuis dadakan kepada mahasiswa. Mahasiswa harus menyelesaikan soal dengan durasi yang dibatasi. Pada kondisi ini, mahasiswa berada pada posisi yang tidak menguntungkan, satu sisi mereka harus menyelesaikan 
soal pada waktu yang telah ditentukan, di sisi lain mereka harus mampu menjawab soal yang diberikan sebagai bukti atas tuturan dosen tersebut.

Kelima, pencitraan. Pencitraan adalah bentuk eufemisme yang dilakukan oleh dosen untuk memberikan penggambaran negatif melalui jabatan, objek benda, lembaga atau suatu tempat. Eufemisme bentuk ini dapat dilihat pada data berikut ini.

(12) D: "Masa level mahasiswa tugasnya masih seperti level SMP!"

M: "Maaf Pak!" (sambil tersenyum malu)

(13) D: "Kalau mengerjakan begini saja tidak bisa, kembali ke SD saja!"

M: .... (diam menunduk malu)

(14) D: "Ini bukan pasar hewan, yang pengen ngobrol di luar saja!"

M: .... (mahasiswa yang merasa disinggung kemudian diam dan menatap dosen dengan serius).

Data (12) terjadi saat konsultasi tugas antara mahasiswa dengan dosen di kelas. Tuturan tersebut terjadi karena salah satu tugas yang dibuat mahasiswa tidak sesuai dengan materi yang telah diajarkan. Pada konteks ini, dosen mencitrakan bahwa tugas yang dibuat mahasiswa seperti tugas yang dibuat anak sekolah menengah pertama. Kondisi ini menunjukkan bahwa pekerjaan mahasiswa tidak lebih baik daripada tugas anak sekolah menengah pertama. Kekerasan simbolik tercermin dengan pencitraan mahasiswa, yakni perguruan tinggi dengan siswa, yakni sekolah menengah pertama. Tidak berbeda jauh dengan data (12), data (13) juga mencitrakan adanya level jenjang pendidikan, pada data ini menunjukkan jenjang perguruan tinggi dengan sekolah dasar. Kondisi ini menunjukkan adanya kekerasan simbolik yang dialami mahasiswa. Kondisi ini mengindikasikan bahwa kemampuan mahasiswa tidak lebih baik dari kemampuan anak sekolah dasar. Berbeda dengan data (12) dan (13) yang menggunakan pencitraan jenjang/ jabatan, data (14) mencitrakan tentang tempat. Kelas atau ruang perkuliahan dicitrakan seperti pasar. Data (14) terjadi saat pembelajaran berlangsung. Dosen sedang menjelaskan topik materi kepada mahasiswa dan mendapati beberapa mahasiswa yang tampak gaduh. Tuturan dosen tersebut tidak disampaikan secara langsung kepada mahasiswa yang mela-kukan kegaduhan, tetapi disuarakan secara lantang. Pada kondisi ini, secara tidak langsung, mahasiswa, baik yang membuat kegaduhan akan melakukan tindakan, yakni diam, takut atau kesal.

Keenam, kegunaan. Kegunaan adalah eufemisme dalam kekerasan simbolik dengan menonjolkan manfaat yang dijanjikan dan dapat diperoleh oleh siswa. Eufemisme bentuk ini dapat dilihat pada data berikut.

(15) D: "Kalau belum baca, apa yang bisa saya komentari?" M: "Maaf Pak."

(16) D: "Hal sepele saja tidak bisa, bagamana kamu bisa minta nilai bagus? bagus?

M: .... (diam tidak bisa menjawab).

(17) D: "kalau menulis paragraf saja tidak bisa, bagaimana nanti membuat skripsi!"

M: .... (terdiam).

Data (15) terjadi saat pembelajaran berlangsung. Tuturan tersebut mengindikasikan bahwa mahasiswa tidak menguasai tugas yang dibuat sehingga dosen terlihat kesal dan kecewa. Dosen berekspektasi bahwa mahasiswa memahami materi dari tugas yang dibuat oleh mahasiswa. Data (16) terjadi saat dosen bertanya jawab dengan mahasiswa. Mahasiswa tidak mampu menjawab pertanyaan yang diajukan dosen. Pada kondisi, mahasiswa seolah menda-pati bahwa dirinya tidak akan mendapatkan nilai bagus. Tuturan yang disampaikan dosen berimplikasi mahasiswa tidak ada harapan, atau mahasiswa menjadi semakin termotivasi untuk belajar agar mendapat nilai bagus. Data (17) terjadi saat dosen mengecek karangan mahasiswa. Dosen merasa kecewa karena mahasiswa tidak mampu menyusun paragraf dengan benar. Dosen seolah mengindikasikan bahwa bila menulis paragraf tidak bisa, otomatis menyusun skripsi juga tidak bisa. Hal ini berimplikasi mahasiswa termotivasi untuk terus belajar menulis paragraf agar menjadi benar, atau mahasiswa menjadi rendah diri dan putus asa dalam menulis paragraf. Data di atas menjelaskan bahwa mahasiswa tidak mampu melakukan pekerjaan yang diberikan oleh dosen dengan benar. Kalimat (15) menggunakan pola pengandaian. Kalimat (16) dan (17) menggunakan pola pertentangan.

Ketujuh, keselarasan. Keselarasan adalah bentuk eufemisme yang dilakukan dengan menunjukkan hal-hal yang harus sesuai atau harus 
selaras yang terjadi dalam pembelajaran. Bentuk eufemisme ini dapat dilihat pada data berikut.

(18) D: "Kalau belum datang, kamu yang harusnya menghubungi saya!"

M: "Iya Pak, maaf Pak."

(19) D: "Sudah tidak ada harapan bisa lulus, jarang masuk begini!"

M: .... (diam tertunduk lesu).

Data (18) terjadi saat akan memulai perkuliahan. Dalam konteks ini, dosen mengingatkan kepada mahasiswa agar selalu menghubunginya bila dosen tidak datang. Kondisi ini mengindikasikan bahwa Kesalahan ada pada mahasiswa. Data (19) terjadi saat perkuliahan usai. Dalam konteks ini, dosen menjelaskan kepada salah satu mahasiswa bahwa ia tidak ada harapan bisa lulus mata kuliah yang diampu dosen tersebut. Hal ini karena mahasiswa tersebut jarang masuk (alpa). Data di atas menunjukkan bahwa terdapat kuasa dosen kepada mahasiswa. Kondisi ini mengindikasikan bahwa mahasiswa, dalam kondisi apapun menjadi pihak yang salah. Mahasiswa seolah-olah tidak memiliki hak untuk mengutarakan pendapatnya atau melakukan pembenaran.

Kedelapan, kemurahatian/ kebaikan. Kemurahatian/ kebaikan adalah bentuk kekerasan simbolik dalam eufemisme yang dilakukan oleh dosen dalam pembelajaran dengan memosisikan diri sebagai pihak yang peduli dan perhatian terhadap mahasiswa dalam mengatasi kesulitan belajar ataupun mendapatkan nilai. Kekerasan simbolik jenis ini dapat dilihat pada data berikut.

(20) D: "Syukur-syukur sudah saya beri nilai $\mathrm{C}+$ !"

M: "Iya sudah Pak."

(21) D: "Sudah untung kamu tidak saya suruh pulang!"

M: "Terima kasih Pak"

(22) D: "Sudah bagus soalnya ada yang dikerjakan, dibanding temanmu tidak ada yang dijawab!" M: "Iya Pak."

Data (20) dituturkan dosen kepada mahasiswa yang mendapat nilai $\mathrm{C}+$. Hal ini mengindikasikan bahwa dosen seolah-olah telah bermurah hati karena memberi nilai $\mathrm{C}+$ kepada salah satu mahasiswa. Mahasiswa, dalam cara apapun akan menjadi tidak berdaya dan pasrah menerima hasil nilai yang disampaikan oleh dosen. Mahasiswa seolah tidak diberi pilihan/kesem- patan untuk mendapatkan penjelasan mengenai nilai yang didapat.

Data (21) dituturkan dosen kepada mahasiswa yang lupa membawa buku catatan. Tuturan "untung tidak saya suruh pulang" semakin menunjukkan kuasa dosen kepada mahasiswa. Mahasiswa seakan menjadi subjek yang bersalah yang mendapat keringanan hukuman.

Data (22) menunjukkan bahwa salah satu mahasiswa mendapat perhatian dosen karena mampu mengerjakan soal dibanding dengan temannya yang tidak dapat menjawab soal. Dosen seolah-olah memberikan poin plus bagi mahasiswa yang telah menjawab soal daripada yang tidak menjawab terlepas jawabannya tersebut belum tentu benar.

Kesembilan, penegasan. Penegasan dalam kekerasan simbolik adalah bentuk eufemisme yang dilakukan oleh dosen sebagai pengontrol jalannya pembelajaran dengan berusaha menjelaskan kepada mahasiswa tentang sikap, baik itu yang berhubungan dengan tingkah laku maupun dari tutur kata yang harusnya dilakukan selama pembelajaran di kelas. Bentuk eufemisme ini dapat dilihat pada data berikut.

(23) D: "Kalau tidak bisa jawab jangan harap lulus mata kuliah ini!"

M: .... (diam dengan raut wajah waswas).

(24) D: "HP-nya dimatikan, sebelum saya kasih pemulung!"

M: .... (beberapa mahasiswa tampak mematikan dan menyimpan Hpnya)

(25) D: Yang belum tuntas sesi konferensi persnya, di luar saja!"

M: .... (suasana kelas seketika menjadi sunyi).

Data (23) dituturkan dosen saat memberikan soal kepada mahasiswa. Tuturan tersebut menyiratkan bahwa penentu kelulusan mata kuliah itu berada pada soal yang diberikan. Posisi dosen yang dominan terlihat jelas dalam tuturan tersebut. Pada kondisi, mahasiswa tentu akan merasa terintimidasi dengan ucapan dosen tersebut. Alih-alih menjawab benar, mahasiswa menjadi tidak percaya diri dengan pekerjaannya.

Data (24) terjadi ketika dosen melihat beberapa mahasiswa bermain gawai dan mendengar bunyi ringtone gawai (handphone) dari salah satu mahasiswa saat pembelajaran berlangsung. Sikap tegas dituturkan oleh dosen dengan 
menyuruh mahasiswa yang tampak membawa gawai untuk mematikan HP-nya.

Data (25) terjadi ketika dosen hendak menjelaskan materi dan mendengar suara-suara gaduh dari mahasiswa. dengan tuturan tidak langsung, dosen menegaskan agar mahasiswa yang membuat suara-suara gaduh tersebut menghentikan percakapannya. Dari kutipan ketiga data di atas, tampak bahwa dosen memegang otoritas penuh jalannya proses pembelajaran.

Bentuk kedua dari mekanisme kekerasan simbolik ini, yaitu sensorisasi. Mekanisme sensorisasi yang ditemukan terdiri atas tiga bentuk, yaitu (1) kedermawanan, (2) kesantunan, dan (3) pemarginalan.

Pertama kedemawanan. Kedermawanan merupakan bentuk kekerasan simbolik dalam mekanisme sensorisasi yang dilakukan oleh dosen sebagai bentuk penekanan pada hal-hal yang bernilai rendah hati. Bentuk sensorisasi ini dapat dilihat pada data berikut.

\section{(26) D: Ini suatu kehormatan bagi saya bisa mengajar kelas internasional!" M: ... (hanya tersenyum)}

Data (26) terjadi saat pembelajaran berlangsung. Pada data tersebut, dosen melakukan praktik pelestarian nilai "kedermawanan" dengan menunjukkan rasa hormatnya terhadap mahasiswa yang diajar. Melalui tuturan yang diujarkan dosen tersebut, mahasiswa menjadi tersanjung dan membuat mereka merasa nyaman dengan dosen tersebut. Namun demikian, tuturan dosen tersebut mengindikasikan bahwa mahasiswa me-mang layak mendapat penghormatan dari dosen karena mereka berada pada kelas internasional, atau mereka menjadi terbebani dengan tuturan tersebut.

Kedua kesantunan. Kesantunan atau sopan santun merupakan bentuk kekerasan simbolik dalam mekanisme sensorisasi yang dilakukan dosen sebagai bentuk penekanan pada hal-hal yang bersifat baik, santun/ beradab. Bentuk kekerasan simbolik ini dapat dilihat pada data (27).

(27) D: "Kelas ini proaktif ya, bisa minta tolong dihapuskan tulisan yang ada di papan?"

M: "Iya Pak!" (maju menuju papan tulis).

Pada (27), kegiatan dilakukan saat dosen hendak memulai perkuliahan. Dosen sengaja menggunakan pilihan bahasa yang santun untuk menyuruh mahasiswa melakukan hal yang diperintahkan. Pada konteks ini, dosen melakukan praktik pelestarian nilai "kesantunan" dengan menggunakan ungkapan permohonan "bisa minta tolong" agar mahasiswa mau bereaksi. Namun demikian, tuturan ini mengindikasikan bahwa mahasiswa tidak peka dengan situasi yang ada di kelas.

Ketiga, pemarginalan. Pemarginalan adalah bentuk kekerasan simbolik dalam mekanisme sensorisasi sebagai bentuk pelestarian yang bernilai buruk, baik itu berupa tingkah laku ataupun tuturan yang muncul selama pembe-lajaran berlangsung. Bentuk kekerasan simbolik ini dapat dilihat pada data berikut.

(28) D: "Kalau tidak mau belajar, tidur di rumah saja!"

M: "Saya mau belajar Pak"

(29) D: "Sudah untung kamu tidak saya suruh balik SMA!"

M: ....(diam dengan wajah lesu)

(30) D: "Kamu tidak akan dapat apa-apa kalau perilakumu seperti itu!" M: "Maaf Pak."

Data (28) terjadi saat kegiatan pembelajaran berlangsung. Tuturan dosen terjadi karena mahasiswa terlihat malas-malasan dalam mengikuti perkuliahan. Dalam data tersebut mahasiswa berada pada posisi orang yang tidak siap belajar dan lebih pantas untuk tidur di rumah, tidak melakukan aktivitas.

Data (29) terjadi saat kegiatan pembelajaran berlangsung. Tuturan dosen terjadi karena salah satu mahasiswa tidak mampu menjawab pertanyaan yang diajukan dosen. Tuturan dosen tersebut secara tegas menunjukkan pemarginalan mahasiswa dengan level SMA.

Data (30) dituturkan dosen ketika pembelajaran akan berakhir. Tuturan dosen terjadi karena mendapati salah satu mahasiswa yang dinilai tidak pantas/sopan dihadapannya. Dalam data tersebut mahasiswa menjadi pihak yang ter-marginalkan karena kuliah menjadi tidak ada artinya karena perilakunya tersebut.

\section{Pembahasan}

Berdasarkan hasil penelitian diketahui bahwa kekerasan simbolik terepresentasi dalam mekanisme eufemisme dan sensorisasi tuturan dosen di kelas Tuturan dosen merupakan alat 
konseptualisasi, alat narasi yang menghubungkan struktur sosial dengan habitus linguistik. Bhambra dan Shilliam (2009:6) mengemukakan bahwa "pembungkaman juga beroperasi dalam konstruksi realitas dengan membingkai dialog antar subjektivitas" sehingga satu suara tertentu menjadi monolitik dan dengan demikian disepakati. Tuturan dosen memegang peranan penting dalam menanamkan pengaruh melalui kekerasan simbolik.

Mekanisme eufemisme, yaitu membuat kekerasan simbolik menjadi tidak tampak, saarsamar, sulit dikenali, dan tidak disadari (Martono, 2012; Ulfah, 2013). Mengacu pada pandangan ini, bentuk eufemisme dalam tuturan dosen, meliputi: (1) keharusan/kewajiban, (2) efisiensi, (3) pemberian bonus, (4) kepercayaan, (5) pencitraan, (6) kegunaan, (7) keselarasan, (8) kemurahatian/ kebaikan, dan (9) penegasan. Sementara itu, mekanisme sensorisasi yaitu menjadikan kekerasan simbolik tampak sebagai sebuah pelestarian semua bentuk nilai yang dianggap sebagai moral kehormatan yang biasanya dipertentangkan dengan moral yang rendah (Martono, 2012: 40). Mengacu pada pandangan ini, bentuk sensorisasi dalam tuturan dosen, meliputi (1) kedermawanan, (2) kesantunan, dan (3) pemarginalan. Kekerasan simbolik dapat dikonstruksi melalui eufemisme dan sensorisasi (Bourdieu dalam Rusdiarti, 2003; Haryatmoko, 2003; Martono, 2012; Ulfah, 2013). Sementara Thapar, dkk. (2016) menggunakan istilah misrecognition (legitimasi), condescension (merendahkan) dan complicity/ consent (keterlibatan/ persetujuan) dalam mengonstruksi kekerasan simbolik.

Hasil temuan penelitian ini berbeda dengan penelitian sebelumnya yang dilakukan oleh Ulfah (2013). Ulfah (2013) menemukan bahwa eufemisasi dalam tuturan guru SMK terdiri atas beberapa bentuk, yaitu perintah, keharusan, efisiensi, pemberian bonus, kepercayaan, pencitraan, harapan, belas kasihan, kegunaan, sopan santun, perjanjian, keselarasan, kemurahatian/ kebaikan, penegasan, dan larangan. Sensorisasi dalam tuturan guru SMK terdiri atas beberapa bentuk, yaitu pemarjinalan, ancaman, paksaan, dan kekecewaan. Pada penelitian yang dilakukan Ulfah (2013a), bentuk mekanisme eufemisme dan sensorisasi mengalami redundansi atau bisa dikatakan berulang, satu bentuk dengan bentuk lain bisa dijadikan satu karena masih terkait, misalnya bentuk 'keharusan' dengan 'perintah', dan bentuk 'ancaman' dengan 'paksaan', walau- pun pada penelitian lainnya, Ulfah (2013b) menemukan bentuk-bentuk eufemisasi yang lebih sederhana dibanding penelitian sebelumnya. Penelitian ini melengkapi penelitian yang dilakukan oleh Ulfah (2013), khususnya pada mekanisme sensorisasi.

Ideologi, budaya, kebiasaan, atau gaya hidup yang diistilah Bourdieu (1991) sebagai habitus tanpa disadari dipaksakan oleh dosen kepada mahasiswa. Bentuk-bentuk eufemisme dan sensorisasi yang dipaparkan pada hasil penelitian di atas menunjukkan bahwa dosen memiliki kuasa mutlak. Pace dan Faules (2006:252) menegaskan bahwa kekuasaan merupakan kemampuan untuk mengarahkan orang lain melakukan suatu tindakan. Tuturan dosen telah merepresentasi kekuasaan dalam bentuk perintah dengan menggunakan kekuasaan jabatan. Tuturan dosen dalam bentuk perintah tercermin hampir di sebagian besar mekanisme eufemisme dan sensorisasi. Dari hasil temuan penelitian tampak bahwa mekanisme eufemisme dilakukan dengan strategi penghalusan maupun penyamaran. Sementara mekanisme sensorisasi dilakukan dengan strategi pelogisan, pemositifan dan pewajaran.

Jufri (2008:87) menjelaskan bahwa salah satu cara melanggengkan kekuasaan yaitu dengan pemberian penghargaan. Penghargaan simbolik yang digunakan dosen dalam tuturan (seperti pada bentuk pemberian bonus) memberi kesan bahwa mahasiswa dihargai oleh guru. Slavin (2009:140) menyatakan bahwa penguatan berupa pujian atau pemberian bonus mempunyai banyak tujuan dalam pengajaran di ruang kelas dan digunakan untuk memperkuat perilaku dan memberikan umpan balik kepada mahasiswa tentang hal yang dilakukan dengan benar. Dengan pemberian bonus/ penghargaan akan dapat menambah atau meningkatkan semangat atau motivasi belajar mahasiswa. Namun, pandangan Slavin ini bertentangan dengan pandangan Bourdieu (1991). Bourdieu (1991) justru menganggap pemberian bonus adalah salah satu bentuk dari kekerasan simbolik karena dengan iming-iming hadiah, mahasiswa secara tidak sadar dipaksa menerima hal yang dikehendaki oleh dosen. Kekerasan simbolik ini bekerja secara nirsadar sehingga seolah-olah patut untuk diikuti. Akibatnya, mahasiswa dipaksa untuk menerima, menjalani, mempraktikkan, dan mengakui bahwa habitus dosen merupakan habitus yang pantas bagi mereka, sedangkan habitus 
mahasiswa merupakan habitus yang sudah selayaknya "diubah atau ditiadakan". Dengan demikian, praktik-praktik yang biasanya diang-gap bermasalah atau 'kekerasan' pada akhirnya mendapatkan penerimaan sosial. Habitus yang terbentuk dan terwujud menjadi sebuah proses internalisasi yang tidak disadari.

Kekerasan simbolik seperti ini menjadi laten dan bersifat nirsadar sehingga mahasiswa ataupun orang lain tidak akan mengganggap dan mengakui hal itu sebagai kekerasan karena didasarkan atas pelimpahan, loyalitas personal, pengakuan, pemberian, yang semuanya diterima sebagai penghormatan etis, kesalehan atau keselamatan.

Hasil penelitian ini bukan ditujukan untuk mencemarkan peran pendidik, dalam hal ini dosen, yang telah bersusah payah mendidik dan melahirkan anak-anak bangsa, melainkan berusaha untuk mengungkap kenyataan adanya praktik kekerasan simbolik di level perguruan tinggi/universitas. Kekuasan yang digunakan oleh dosen sebagai pengendali jalannya pembelajaran justru akan mengekang kebebasan berpikir dan bertindak, keingintahuan, dan kreativitas mahasiswa. Oleh karenanya, hal ini bukanlah menjadi suatu persoalan yang luar biasa bila dari sistem pendidikan seperti ini, pada akhirnya, menciptakan mahasiswa-mahasiswa yang patuh dan tidak memiliki orientasi atas diri dan lingkungannya. Dalam bahasa yang lebih ekstrem, dapat dikatakan universitas hanya menghasilkan para "penghamba intelektual", mahasiswamahasiswa yang sengaja dijejali dengan berbagai dogma dan aturan-aturan kampus yang ajeg yang membatasi kreativitas serta ruang berpikir mereka.

Dampak kekerasan simbolik jauh lebih berbahaya dibanding dengan kekerasan yang sifatnya nyata, misalnya kekerasan fisik. Hal ini karena kekerasan simbolik dalam menguasai dan memaksa korbannya berkelindan dengan semua bentuk tindakan, struktur pengetahuan, dan struktur kesadaran individual. Hal ini, pada akhirnya, akan menguasai sisi kehidupan mereka, mulai dari cara bernalar, cara bertindak, cara memandang sesuatu, sikap hidup, kondisi psikis, sampai dengan tindakan nyata. Bila kondisi ini terus menerus terjadi, tidak menutup kemungkinan dapat melahirkan sikap dan tindakan-tindakan destruktif.

Dosen sebagai pendidik, sudah selayaknya mengubah pola pikir feodal yang sudah meng- akar dalam diri mereka. Dosen harus bersifat terbuka dan beradaptasi dengan situasi kelas yang beragam, membangun budaya demo-kratis, 'tepa selira', nondiskriminasi, bukan sindir-sindiran, ataupun perundungan, atau diistilahkan Suharno, dkk., (2013:15) sebagai prinsip Pendidikan rajut damai. Di samping itu, dosen hendaknya dapat bersikap adil, sejajar, atau paralel. Sikap yang memandang sama benar dan sama baiknya berbagai pendapat dan kebiasaan tiap orang. Keragaman hanyalah sekadar perbedaan cara pandang terhadap sesuatu (Panikkar, 1999: 534). Hal ini karena pengalaman yang dimiliki tiap orang berbeda. Dosen harus pula mampu membudayakan pola pikir dan pola tutur yang santun tapi terbuka. Dengan demikian, mahasiswa merasa 'dimanusiakan' dan secara otomatis mereka juga menghormati dosennya.

\section{SIMPULAN}

Kekerasan simbolik dalam dunia pendidikan merupakan hal yang sulit dilihat dan diidentifikasi. Kekerasan simbolik dalam pendidikan membentuk perilaku, pemikiran, dan kepercayaan yang dapat diterima dalam ruang sosial tertentu. Norma-norma perilaku tertanam dalam praktik-praktik sosial, dan dipandang sebagai apa adanya, sebagaimana adanya, dan seperti apa adanya. Dengan menggunakan alasan "kehormatan moral" dan "moral rendah", seorang pendidik sering melakukan tindak kekerasan dengan alasan menegakkan disiplin. Peserta didik secara tidak langsung dipaksa untuk menerima nilainilai yang dipersepsikan dengan baik tanpa mampu berpikir kritis. Alih-alih sebagai bentuk kepedulian pendidik terhadap peserta didik, segala tindak kekerasan simbolik yang terjadi seolah menjadi keharusan yang 'berterima' sebagai suatu kebaikan. Representasi kekerasan simbolik dalam pendidikan tinggi terjadi dalam situasi pembelajaran yang melibatkan dosen dengan mahasiswa di kelas. Hasil penelitian menunjukkan bahwa kekerasan simbolik terepresentasi dalam mekanisme eufemisme dan sensorisasi. Bentuk eufemisme dalam tuturan dosen berupa (1) keharusan/ kewajiban, (2) efisiensi, (3) pemberian bonus, (4) kepercayaan, (5) pencitraan, (6) kegunaan, (7) keselarasan, (8) kemurahatian/ kebaikan, dan (9) penegasan; sementara bentuk sensorisasi tuturan dosen berupa (1) ke- 
dermawanan, (2) kesantunan, dan (3) pemarginalan.

Bagaimanapun, kekerasan simbolik tidak bisa hanya dimaknai sebagai bentuk kepedulian dosen dengan melakukan upaya-upaya pendisiplinan karena ada satu sisi dalam diri mahasiswa yang terluka secara psikis dan mentalnya. Bila kondisi ini terus menerus terjadi, tidak menutup kemungkinan dapat melahirkan sikap dan tindakan-tindakan destruktif. Sikap kritis diperlukan untuk menetralisasi praktik kekerasan simbolik dalam pembelajaran. Sikap ini dapat tercapai bila tercipta kerja sama yang solid antara dosen dengan mahasiswa. Satu hal

\section{DAFTAR PUSTAKA}

Amirulloh, S. 2018. Understanding of Symbolic Violence in Realizing The Conducive Educational Ecosystem (Study on MAN Kota Batu). Jurnal Partisipatoris, 1 (1): 36-44.

Bhambra, G. K., and Shilliam, R. 2009. Silent and Human Right, in Silencing Human Rights: Critical Engagements with a Contested Project. Basingstoke: Palgrave Mac Millan, 1-19.

Bernstein, B. 2000. Pedagogy, Symbolic Control and Identity: Theory, Research, Critique, revised edn. Lanham, MD: Rowman \& Littlefield.

Bourdieu, P. 1991. Language and Symbolic Power (J. B. Thompson, Ed., G. Ramond and M. Adamson, Trans.). Cambridge: Harvard University Press and Polity Press.

Daradjat, Z., et al. 2002. Ilmu Pendidikan Islam. Cet. II. Jakarta: Bulan Bintang.

Foucault, M. 1995. Discipline and Punish: The Birth of the Prison, trans. A. Sheridan, 2nd edn. New York: Vintage Books.

Goldstein, Rebecca A. 2005. "Symbolic and Institutional Violence and Critical Educational Spaces: In the Name of Education. Journal of Peace Education, 2:33-52.

Haryatmoko. 2003. Menyingkap Kepalsuan Budaya Penguasa. Jurnal Basis, 11: 5-23.

Jalaluddin. 2001. Teologi Pendidikan. Jakarta: PT Raja Grafindo Persada.

Jufri. 2008. Analisis Wacana Kritis. Makasar: Badan Penerbit Universitas Negeri Makasar.

Martono, N. 2012. Kekerasan Simbolik di Sekolah: Sebuah Ide Sosiologi Pendidikan Pierre Bourdie. Depok: PT Raja Grafindo Persada.

Miles, M.B, Huberman, A.M, dan Saldana, J. 2014. Qualitative Data Analysis, A Methods Soucebook, Edition 3. USA: Sage Publications

Pace, W. R. \& Don F. F. 2006. Komunikasi Organisasi. Bandung: PT. Remaja Rosda Karya. yang perlu diingat bahwa setiap individu memiliki hak untuk menyatakan pendapatnya sendiri, tertulis maupun lisan, baik ataukah buruk, namun satu hal yang tidak boleh ditinggalkan adalah pertanggungjawaban terhadap pendapat itu.

\section{UCAPAN TERIMA KASIH}

Ucapan terima kasih disampaikan peneliti kepada mitra bestari (reviewers) yang telah memberikan masukan, kritik, dan saran perbaikan dalam penulisan artikel ini.

Panikkar, R. 1999. Four Attitude. In Garry E. Kessler (Ed.). Philosophy of Religion: Toward a Global Perspective. Canada: Wardsworth Publishing Company.

Rusdiarti, S. R. 2003. "Bahasa, Pertarungan Simbolik, dan Kekuasaan.” Jurnal Basis, 11: 12-21.

Schubert, J. D. 1995 From a politics of transgression toward a theory of reflexivity. American Behavioural Scientist, 38(7), 1003-1017.

Scott, B. C. 2012. Caring Teachers and Symbolic Violence: Engaging the Productive Struggle in Practice and. Research. Educational Studies, 48:530 -549. doi: 10.1080/00131946. 2012.733279.

Slavin, R. E. 2009. Cooperative Learning (Teori, Riset, dan Praktik). Bandung: Nusa Media.

Suharno, S \& Gendri, H. 2013. Model PeaceBuilding Teaching and Learning: Sebuah Intervensi Pencegahan Kekerasan melalui Pendidikan Formal. (Online), (http://eprints. uny.ac.id/23718/pdf), diakses pada 27 Juli 2019).

Thapar-Björkert, S. Samelius, Sanghera, L., Gurchathen, S. 2016. Exploring Symbolic Violence in The Everyday: Misrecognition, Condescension, Consent and Complicity. Feminist Review.. 112 (1):144-162.

Ulfah. 2013a. Kekerasan Simbolik dalam Wacana Pembelajaran. Jurnal Penelitian Pendidikan INSANI, 14 (1):51-58.

Ulfah. 2013b. Eufemisme sebagai Mekanisme Kekerasan Simbolik dalam Pembelajaran di Sekolah. Jurnal Kreatif Untad. 16 (3):80-86.

Zuhra, W. U. N. 2019. Dosen Predator yang Masih Berkeliaran di UIN Malang. (Online), (tirto.id), diakses 20 Mei 2019. 